\title{
KEBIJAKAN PENGEMBANGAN PERMUKIMAN VERTIKAL DI PROVINSI DKI JAKARTA
}

\author{
Oleh: Budiana Setiawan*
}

\begin{abstract}
The percentage of green open space (RTH) in Jakarta is only 9.6\%. It is very lower than the minimum limit which be set by the World Health Organization (WHO), which is $30 \%$ of total area of a city. One cause of the least of remaining green open space in Jakarta is the fast growing of settlements. To prevent green open space in Jakarta is not diminished, Jakarta Provincial Government needs to change the strategy of development of settlements from horizontal to vertical. Vertical settlement is shaped in flats or apartments. Flats or apartments are the right alternative to answer the high demand of land for settlement on one side and still be able to maintain the integrity of the vast green open space on the other side. Despite this effort to realize the vertical settlements are blocked by three factors, i.e.: society, developer, and the Provincial Government of Jakarta. To overcome these problems, there are three factors to consider in determining government policy, namely: discourse / narratives, politic interest, and actors / network.
\end{abstract}

Keywords: green open space (RTH), vertical settlement, flats, apartments, Province of Jakarta.

\section{LATARBELAKANG}

Provinsi DKI Jakarta yang sekaligus sebagai ibukota Republik Indonesia merupakan daerah perkotaan yang sangat padat penduduknya. Kepadatan penduduk yang tinggi menyebabkan di Kota Jakarta hanya tersisa sedikit Ruang Terbuka Hijau (RTH), yang antara lain berupa hutan kota, taman, lapangan olah raga, lahan pertanian kota, maupun tempat terbuka lainnya. Dengan luas sekitar $664,01 \mathrm{~km}^{2}$, penduduk Kota Jakarta mencapai 9.223.000 juta jiwa, dengan kepadatan penduduk 12.459 jiwa/ $\mathrm{km}^{2}$ (Badan Pusat Statistik, 2009: 10, 8283). Kepadatan penduduk sebuah kota berkorelasi dengan kebutuhan lahan untuk permukiman. Semakin padat penduduknya, maka semakin banyak lahan yang dibutuhkan untuk permukiman. Di sisi lain, sebuah kota besar sangat memerlukan RTH, karena berfungsi untuk paru-paru kota, mengurangi polusi udara, menyimpan air tanah, mengendalikan banjir, maupun prasarana rekreasi warga kota.

Berdasarkan peraturan dari World Health Organization (WHO), batas minimal RTH untuk sebuah kota besar adalah 30\% dari keseluruhan luas kota. Bagaimana dengan Kota Jakarta? Luas RTH di Kota Jakarta saat ini hanya tinggal 9,6\%, jauh di bawah batas minimal yang

*Peneliti di Pusat Penelitian dan Pengembangan Kebudayaan, Badan Penelitian dan Pengembangan, Kementerian Pendidikan dan Kebudayaan. 
30 JURNAL ILMIAH MIMBAR DEMOKRASI

ditetapkan oleh WHO ("Pembahasan RTRW: Permukiman jadi Vertikal". Kompas, Selasa 19 Oktober 2010, hlm. 26 kolom 1-3). Hal ini menyebabkan Jakarta senantiasa menghadapi berbagai persoalan yang tidak pernah teratasi, seperti banjir, polusi udara, kekurangan air bersih, kebakaran permukiman padat penduduk, dan sebagainya.

Untuk mencegah agar RTH di Jakarta tidak semakin berkurang, Pemerintah Provinsi DKI Jakarta saat ini perlu mengubah strategi pembangunan permukiman, dari permukiman horizontal menjadi permukiman yang bersifat vertikal. Permukiman horizontal adalah perumahan atau perkampungan padat penduduk, di mana satu petak tanah dengan luas tertentu hanya terdiri dari satu unit rumah dan pada umumnya ditinggali oleh satu keluarga. Permukiman horizontal ini menyebabkan kebutuhan lahan untuk permukiman menjadi sangat luas.

$$
\text { Permukiman vertikal adalah }
$$
berbentuk rumah susun atau apartemen. Pengertian rumah susun atau apartemen menurut Undang-Undang nomor 16 tahun 1985 tentang Rumah Susun, Pasal 1 Ayat 1 adalah "bangunan gedung bertingkat yang dibangun dalam suatu lingkungan, yang terbagi dalam bagian-bagian yang distrukturkan secara fungsional dalam arah horizontal maupun vertikal dan merupakan satuan-satuan yang masing-masing dapat dimiliki dan digunakan secara terpisah, terutama untuk hunian, yang dilengkapi dengan bagian bersama, benda bersama, dan tanah bersama (Undang-Undang Nomor 16 tahun 1985 tentang Rumah Susun). Rumah susun atau apartemen ini merupakan alternatif yang tepat untuk menjawab tingginya kebutuhan lahan untuk permukiman di satu sisi dan tetap dapat menjaga keutuhan luas RTH di sisi lain. Jika permukiman vertikal sudah terwujud, maka sedikit demi sedikit masyarakat yang tinggal di permukiman yang tidak layak huni (misalnya: bantaran sungai, pinggir rel kereta api, sekitar tempat pembuangan sampah, perkampungan yang sangat padat, dan lainlain) dapat dipindahkan ke rumah susun atau apartemen sederhana. Dengan demikian, bekas lahan permukiman dapat dialihfungsikan kembali menjadi RTH. Selanjutnya, dalam kurun waktu tertentu target RTH 30\% dari luas Kota Jakarta dapat terpenuhi. ("Pembahasan RTRW: Permukiman jadi Vertikal". Kompas, Selasa 19 Oktober 2010, hlm. 26 kolom 13). 


\section{PERMASALAHAN}

Berdasarkan pemaparan di atas, ada tiga pihak yang saling terkait dalam upaya mewujudkan permukiman vertikal, yaitu: masyarakat (khususnya yang berpenghasilan rendah dan tinggal di permukiman-permukiman yang tidak layak huni), pengembang/ developer, dan Pemerintah Provinsi DKI Jakarta.

1. Masyarakat

Untuk mewujudkan permukiman vertikal, pihak yang berkompeten untuk diperhatikan adalah masyarakat yang akan menempati permukiman vertikal itu sendiri. Namun kendalanya adalah, dengan bermukim di rumah susun atau apartemen, masyarakat harus mengubah perilakunya agar sesuai dengan kondisi lingkungan permukiman vertikal, khususnya pada aspek-aspek keselamatan.

2. Pengembang/ Developer

Pengembang atau developer adalah pihak yang mencari dan membeli lahan-lahan milik masyarakat maupun aset pemerintah, untuk kemudian dibangun menjadi permukiman, gedung perkantoran, atau pusat industri. Mereka lah yang kemudian menjual unit-unit permukiman kepada masyarakat. Para pengembang senantiasa berorientasi bisnis, sehingga cenderung berusaha membangun sebanyak mungkin gedung, pusat perindustrian, maupun permukiman, tanpa memperhatikan ketentuan RTH.

3. Pemerintah Provinsi DKI Jakarta

Pemerintah melalui Menteri Perumahan Rakyat (Menpera) pernah mencanangkan program 1000 rumah susun keluarga miskin (rusunami). Melalui program tersebut diharapkan orientasi masyarakat pada permukiman horizontal dapat perlahan-lahan dialihkan ke permukiman vertikal (Kebijakan Perumahan Pemerintah Jangan Sampai Ketinggalan Momentum, http://www.antaranews.com/ berita/1268519741/kebijakanperumahan-pemerintah-jangansampai-ketinggalan-momentum, diunduh tanggal 30 Oktober 2010, jam 8.27).

Masing-masing pihak tersebut di atas memiliki kepentingan-kepentingan tersendiri berkaitan dengan pengadaan rumah susun atau apartemen sederhana. Perbedaan kepentingan tersebut menyebabkan terjadinya konflik antara masyarakat selaku konsumen dan pengembang selaku penyedia permukiman untuk masyarakat, dan pemerintah dengan kebijakan-kebijakannya yang harus mampu meningkatkan luas RTH di DKI Jakarta. 
Permasalahan di atas berkaitan dengan teori pengembangan kebijakan lingkungan (environtmental policy) dari Andrew Blowers. Menurut Blowers, kebijakan lingkungan senantiasa menghadapi dua kepentingan yang saling bertolak belakang, yaitu kepentingan pelestarian lingkungan dan kepentingan sosial masyarakat. Dalam perspektif masyarakat, kepentingan pelestarian lingkungan seringkali dianggap radikal dan fundamental, sehingga mengubah institusi sosial dan gaya hidup masyarakat. Isu pelestarian lingkungan tersebut menjadi kuat karena merupakan bagian dari isu nasional dan bahkan global tentang pelestarian lingkungan (Andrew Blowers, 1997: 846). Perspektif tersebut juga berkaitan dengan wacana tentang konsep masyarakat modern dan perubahan sumberdaya. Salah satu pendekatan yang digunakan adalah modernisasi ekologi memegang peranan dalam pelestarian lingkungan. Untuk itu harus diakomodasi dalam bentuk perubahan terhadap proses produksi dan adaptasi institusional masyarakat. Teori ini digunakan untuk menjawab pertanyaan tentang apakah isu pelestarian lingkungan dapat diserap ke dalam kebijakan dengan cara adaptasi atau bahkan memengaruhi secara keseluruhan dari cara pengorganisasian dan pengelolaan kehidupan masyarakat (Andrew Blowers, 1997: 847).

\section{KEBIJAKAN SAAT INI}

Pemerintah sebenarnya telah membuat Rencana Tata Ruang Wilayah (RTRW) untuk wilayah DKI Jakarta dan sekitarnya. Berkaitan dengan pengaturan RTRW untuk wilayah DKI Jakarta dan sekitarnya, Pemerintah Pusat telah mengeluarkan Undang-Undang no. 26 tahun 2007 tentang Penataan Ruang dan Peraturan Presiden no. 54 tahun 2008 tentang Penataan Kawasan Jabodetabekpunjur (Jakarta, Bogor, Depok, Tangerang, Bekasi, Puncak, dan Cianjur). Undang-undang dan peraturan presiden tersebut yang kemudian digunakan sebagai rujukan dalam upaya pengaturan RTRW di wilayah Provinsi DKI Jakarta untuk tahun 2010-2030. Dari RTRW tersebut, luas lahan yang diperlukan untuk permukiman mencapai 62\%, RTH hanya 13,94\%, sedangkan sisanya (24,56\%) untuk perkantoran, perindustrian, dan pelayanan masyarakat (RTH disesuaikan dengan Kebutuhan, http: www.poskota.co.id/ berita-terkini/ 2010/03/26/ rth-disesuaikandengan-kebutuhan, diunduh tanggal 30 Oktober 2010 jam 9.14).

Pengaturan RT/RW tersebut menunjukkan ketimpangan dan ketidakkonsistenan pemerintah karena persentase lahan untuk RTH sangat jauh di bawah ketentuan minimal dari WHO, yaitu 30\%. Pengaturan tersebut juga menunjukkan kemunduran dalam 
penetapan luas lahan yang dijadikan RTH dari waktu ke waktu. Dalam RUTR Jakarta tahun 1965-1985, RTH ditargetkan mencapai $37,2 \%$ dari luas Kota Jakarta, sedangkan pada tahun 1985-2005 turun menjadi 25,85\%, dan kini dalam RTRW Kota Jakarta 2000-2010 turun drastis menjadi 13,94\% (Hirworo Yoga dan Yori Antar, 2010: 98).

\section{Berkembangnya permukiman} horizontal yang tidak terkendali, sehingga menyebabkan RTH secara riil di DKI Jakarta bukan lagi 13,94\%, melainkan hanya tinggal $9,6 \%$, sebenarnya tidak terlepas dari kesalahan kebijakan pemerintah provinsi pada masa lalu. Sejak tahun 1970-an pemerintah telah menyerahkan ribuan hektar tanah cadangan kepada pengembang untuk kebutuhan pembangunan kota dan memberikan izin pembebasan tanah untuk keperluan perumahan. Hal ini menyebabkan para pengembang mempunyai kewenangan penuh untuk membangun sebanyak mungkin gedung-gedung perkantoran, perindustrian, dan permukiman, tanpa memperhitungkan RTH. Pembangunan RTH dianggap tidak memberikan keuntungan apapun bagi pengembang karena tidak bernilai secara ekonomi. Model pembangunan perumahan dengan investasi swasta tersebut menyebabkan pemerintah sulit untuk mengontrol peruntukan lahan berdasarkan Rencana
Umum Tata Ruang (RUTR). Model pembangunan perumahan oleh pengembang pemodal swasta tersebut pada akhirnya melenceng dari ketentuan Undang-Undang Pokok Agraria tahun 1960 pasal 13 yang menugaskan pemerintah untuk mencegah praktik spekulan dan monopoli tanah di perkotaan (Menuju Kebijakan Perumahan yang Memihak Rakyat. http://yaminsh. wordpress.com/2008/10/11/menujukebijakan-perumahan-yang memihakrakyat/. diunduh tanggal 30 Oktober 2010, jam 8.14).

Di sisi lain, ada langkah-langkah yang dilakukan Pemerintah Provinsi DKI Jakarta untuk mempertahankan luas RTH pada lahan-lahan yang terlanjur dibeli pengembang, yaitu dengan mewajibkan para pengembang mengalokasikan sebagian lahan yang dibelinya untuk RTH. Pengembang yang akan membangun gedung apartemen atau rumah susun wajib menyisakan $60 \%$ dari lahan yang ada untuk RTH, sedangkan untuk perumahan horizontal wajib menyisakan $40 \%$ dari luas lahan yang ada untuk RTH. Pemerintah provinsi juga akan membebaskan lahanlahan permukiman liar dan kumuh untuk dikembalikan pada fungsinya sebagai RTH (RTH disesuaikan dengan Kebutuhan, http://www.poskota.co.id/berita-

terkini/2010/03/26/rth-disesuaikan-dengan- 
kebutuhan, diunduh tanggal 30 Oktober 2010 jam 9.14)

\section{EVALUASI KEBIJAKAN}

Berkaitan dengan permasalahan tersebut di atas, terdapat tiga faktor yang saling berkaitan, yaitu: discourse/ narratives, politic interest, dan actors/ network. Ketiga faktor tersebut perlu dipertimbangkan dalam menentukan kebijakan.

1. Discourse/ Narratives (Wacana/ Narasi)

Jika kebijakan pembangunan permukiman masih bersifat horizontal, maka lahan RTH di Jakarta semakin habis. Jakarta menjadi semakin tidak nyaman karena tidak memiliki paruparu kota, tempat untuk mengurangi polusi udara, menyimpan air tanah, dan mencegah banjir. Untuk itu diperlukan kebijakan pembangunan permukiman yang bersifat vertikal. Discourse atau narrative tersebut nantinya dapat digunakan untuk menjawab pertanyaan-pertanyaan, seperti: mengapa kebijakan tersebut perlu dikembangkan, apa efeknya bila dikembangkan, bagaimana narasi itu berfungsi, problem-problem apa saja dari narasi tersebut, dan mengapa narasi tersebut bersifat meresap.
2. Politic Interest (Kepentingan Politik)

Pembangunan permukiman vertikal akan berimplikasi terhadap terjaganya areal RTH. Bahkan bila memungkinkan, luas lahan RTH semakin bertambah karena banyak warga yang semula tinggal di bantaran sungai, pinggir rel kereta api, atau sekitar tempat pembuangan sampah yang beralih ke rumah susun atau apartemen sederhana. RTH juga mempunyai fungsi penting untuk mengurangi polusi udara, mempertahankan simpanan air tanah, meminimalisir banjir, dan menjadi pusat rekreasi dan olah raga bagi masyarakat. Upaya untuk mempertahankan lahan RTH sangat berkaitan dengan citra pemerintah terhadap masyarakatnya.

3. Actors (Aktor/ Pelaku)

Aktor-aktor yang terlibat dalam pembangunan rumah susun atau apartemen sederhana adalah instansi pemerintah selaku institusi yang berwenang mengatur tata ruang kota, pengembang/ developer selaku pelaksana pembangunan permukiman, maupun masyarakat selaku pihak pengguna yang akan menempati permukiman-permukiman vertikal. 
Adapun narasi-narasi yang perlu diungkapkan pada masing-masing aktor adalah sebagai berikut.

1. Masyarakat

Untuk mewujudkan permukiman vertikal, pemerintah provinsi harus meyakinkan pada masyarakat bahwa lebih banyak keuntungan yang diperoleh dengan tinggal di rumah susun atau apartemen daripada tinggal di permukiman horizontal. Beberapa wacana yang dapat digulirkan untuk memotivasi masyarakat tinggal di permukiman vertikal, antara lain:

a. Keterbatasan aksesibilitas untuk keluar-masuk rumah, meliputi ganggang, jalan sempit, dan akses jalan setapak menuju rumah.

b. Mudah terjadi konflik sosial, karena ruang yang terbatas harus digunakan bersama-sama oleh orang banyak.

c. Ancaman banjir pada musim hujan dan kekurangan air bersih pada saat musim kemarau karena hilangnya daerah tangkapan air dan resapan air.

\section{Pengembang/ Developer}

Pembangunan rumah susun maupun apartemen sederhana memerlukan biaya yang sangat tinggi bila dibandingkan dengan pembangunan perumahan horizontal. Hal ini dikarenakan tuntutantuntutan standar keamanan dan fasilitas yang harus dipenuhi, seperti: konstruksi bangunan yang kuat, penyediaan air dan listrik dalam jumlah besar, serta penyediaan fasilitas penunjang (lift, tangga darurat, peralatan pemadam kebakaran, dan lain-lain). Hal ini menyebabkan pihak pengembang tidak dapat menjual unit-unit rumah susun dengan harga murah, sementara sasaran konsumen pembeli rumah susun atau apartemen sederhana yang ditetapkan oleh pemerintah provinsi adalah masyarakat kelas menengah ke bawah. Kondisi ini sebenarnya bisa diatasi apabila pemerintah memberikan bantuan pinjaman dengan bunga ringan, atau yang lebih dikenal dengan istilah Kredit Pemilikan Rumah (KPR) kepada masyarakat yang berdaya beli rendah, sehingga mereka dapat membeli unit-unit rumah susun atau apartemen sederhana. Namun persoalannya tidak hanya berhenti sampai di situ. Biaya-biaya yang dikeluarkan pemilik rumah untuk operasional apartemen relatif tinggi, misalnya: pemeliharaan lift, pompa air berdaya sedot tinggi, tenaga keamanan (karena pemilik rumah harus meninggalkan kendaraan di lantai basement), dan lainlain. Beban operasional tersebut harus ditanggung oleh masyarakat setelah mereka menghuni rumah susun atau apartemen sederhana, sehingga mengurangi minat masyarakat untuk membeli rumah susun atau apartemen sederhana. Beban operasional ini relatif tidak terdapat pada perumahan yang 
bersifat horizontal. Untuk mengatasi hal itu pemerintah juga harus memberikan subsidi kepada masyarakat berpenghasilan rendah rendah untuk biaya-biaya operasional selama tinggal di rumah susun.

\section{Pemerintah}

Agar konsep permukiman vertikal dapat terwujud, pemerintah provinsi harus secara tegas membatasi izin pembelian lahan untuk permukiman oleh para pengembang. Lahan-lahan yang di dalam RTRW sudah diperuntukkan bagi RTH sama sekali dilarang untuk dibangun. Salah satu cara yang untuk membatasi pengembang membeli lahan untuk permukiman horizontal adalah menetapkan harga tanah yang tinggi dan izin pembangunan yang terbatas. Dengan harga tanah yang tinggi dan izin pembanguna yang terbatas, biaya yang dikeluarkan pengembang untuk membeli lahan yang luas untuk permukiman horizontal menjadi lebih tinggi dibandingkan dengan membangun permukiman vertikal yang hanya memerlukan lahan yang lebih sempit. Setelah selesai membangun, harga jual permukiman horizontal pun menjadi lebih tinggi dibandingkan harga jual unitunit permukiman di rumah susun. Apabila kebijakan ini dilakukan oleh pemerintah, maka dengan sendirinya masyarakat akan beralih dari bertempat tinggal di permukiman horizontal menjadi bertempat tinggal di permukiman vertikal.

Berkaitan dengan permasalahan di atas, Rebecca Sutton menyampaikan bahwa ada lima model yang digunakan untuk proses pembuatan kebijakan, yaitu:

1. Policy as The incrementalist model (Model Pengangkatan)

Pembuat kebijakan menentukan beberapa alternatif pemecahan permasalahan, kemudian cenderung untuk menentukan pilihan yang secara garis besar berbeda dengan kebijakan yang sudah ada sebelumnya. Pada akhirnya tidak ada ketentuan kebijakan yang optimal. Kebijakan semacam ini merupakan cara yang tepat karena memuaskan semua pihak yang terlibat di dalamnya. Semua pihak akan menyetujui kebijakan tersebut daripada menentukan kebijakan yang terbaik, yang tentu tidak memuaskan semua pihak, untuk memecahkan masalah tersebut.

2. Policy as The mixed scanning model (Model Penyampuran)

Posisi kebijakan ini berada di antara model kebijakan rasional/ linier dan incrementalist. Model ini membagi keputusan kebijakan menjadi dua, yaitu kebijakan makro dan mikro. Kebijakan makro untuk hal-hal yang bersifat fundamental, sedangkan kebijakan mikro untuk hal-hal yang bersifat kecil. 
Model rasional/ linier berimplikasi pada pertimbangan menyeluruh terhadap semua pilihan secara detail. Sedangkan model incrementalist lebih merekomendasikan untuk melihat pilihan-pilihan kebijakan yang sudah ada sebelumnya.

3. Policy as an Argumentalist Model (Model Argumental)

Kebijakan ini ditentukan berdasarkan debat antara penguasa (pemerintah) dengan kelompok-kelompok masyarakat. Masing-masing pihak mengklaim dan menjustifikasi kebijakan yang diinginkan dengan argumentasi-argumentasi yang kritis.

4. Policy as Social Experiment Model (Model Eksperimen Sosial)

Kebijakan ini didasarkan pada perubahan sosial sebagai proses trial and error (coba dan gagal). Dalam hal ini hipotesis-hipotesis yang ada diuji di lapangan, sehingga pada akhirnya diperoleh kebijakan yang dianggap tepat.

5. Policy as Interactive Learning Model (Model Pembelajaran Interaktif)

Kebijakan ini didasarkan pada kritikankritikan atas pengembangan kebijakan sebelumnya yang bersifat top down (dari atas turun ke bawah), tidak bottom up, yaitu dari komunitas tempat kebijakan tersebut diimplementasikan (Rebecca Sutton. 1999: 10-11).
Berdasarkan pemaparan terhadap ketiga faktor yang saling berkaitan di atas (discourse/ narratives, politic interest, dan actors/ network), model kebijakan yang tampaknya paling tepat untuk mengatasi permasalahan di dalam mewujudkan permukiman vertikal adalah "Policy as The Mixed Scanning Model". Sebagaimana telah disebutkan di atas, model ini membagi kebijakan menjadi dua, yaitu kebijakan makro dan kebijakan mikro. Kebijakan makro sebenarnya telah tertuang di dalam Undang-Undang Nomor 26 tahun 2007 tentang Penataan Ruang dan Peraturan Presiden no. 54 tahun 2008 tentang Penataan Kawasan Jabodetabekpunjur (Jakarta, Bogor, Depok, Tangerang, Bekasi, Puncak, dan Cianjur). Melalui undang-undang dan peraturan presiden tersebut, luas lahan untuk permukiman yang mencapai $62 \%$ di dalam RTRW Provinsi DKI Jakarta perlu dikurangi, dengan memberi persentase yang lebih besar terhadap RTH, sehingga target $30 \%$ dapat dicapai.

Untuk mewujudkan RTH yang mencapai $30 \%$ tersebut, diperlukan beberapa kebijakan yang lebih bersifat mikro, antara lain yang diamanatkan dalam Undang-Undang Nomor 16 tahun 1985 tentang Rumah Susun. Undang-undang ini diupayakan dapat mendorong pembangunan rumah susun-rumah susun dalam jumlah yang lebih banyak, sesuai 


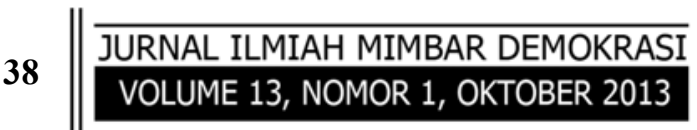

dengan semangat program 1000 rusunami yang pernah dicanangkan oleh Menteri Perumahan Rakyat.

Kebijakan yang lebih mikro lagi adalah ketentuan dari Pemerintah Provinsi DKI Jakarta yang mewajibkan para pengembang mengalokasikan sebagian lahan yang dibelinya untuk RTH. Pengembang yang akan membangun gedung apartemen atau rumah susun wajib menyisakan $60 \%$ dari lahan yang ada untuk RTH, sedangkan untuk perumahan horizontal wajib menyisakan $40 \%$ dari luas lahan yang ada untuk RTH.

\section{KESIMPULAN}

Untuk mencegah agar RTH di Jakarta tidak semakin berkurang, Pemerintah Provinsi DKI Jakarta saat ini perlu mengubah strategi pembangunan permukiman, dari permukiman horizontal menjadi permukiman yang bersifat vertikal. Dalam hal ini rumah susun atau apartemen sederhana merupakan alternatif yang tepat untuk mengatasi tingginya kebutuhan lahan untuk permukiman di satu sisi dan tetap dapat menjaga keutuhan luas lahan RTH di sisi lain. Hal ini yang oleh Andrew Blowers disebut sebagai dua kepentingan yang saling bertolak belakang namun harus diselaraskan, yaitu kepentingan pelestarian lingkungan yang dapat diselaraskan dengan kepentingan sosial masyarakat.
Untuk mengatasi permasalahan tersebut, Pemerintah Provinsi DKI Jakarta perlu memperbaiki kesalahan kebijakan pada masa lalu yang memberi kewenangan penuh terhadap para pengembang, sehingga pemerintah kesulitan untuk mengontrol peruntukan lahan berdasarkan RUTR. Untuk mencegah agar luas lahan RTH tidak semakin berkurang, pemerintah mewajibkan para pengembang untuk mengalokasikan sebagian lahan yang dibelinya untuk RTH. Di samping itu pemerintah perlu melakukan sosialisasi agar masyarakat mau berpindah tempat tinggal dari permukiman horizontal yang padat dan kumuh ke permukiman vertikal yang relatif lebih teratur.

\section{DAFTAR PUSTAKA}

Adlin, Budhiawan. Analisis Yuridis mengenai Pembangunan Rumah Susun Sederhana Sewa Pasar VII, Martubung, Kecamatan Medan Labuhan. http://www.researchgate.net/publica tion/42322820_Analisis_Yuridis_M engenai_PengadaanPembangunā Rumah_Susun_Sederhana_Sewa_P asar_VII_Martubung_Kecamatan_Medan_Labuhan, diunduh tanggal 21 Desember 2010 jam 23.43.

Aji, Mochammad Taruna. Pembodohan Publik: Rumah Susun. http://www.berita8.

com/news.php?cat=12\&id=1012, 
diunduh tanggal 21 Desember 2010 pukul 23.26

Badan Pusat Statistik (2009). Statistik Indonesia 2009.

Blower, Andrew (1997). "Environmental Policy: Ecological Modernisation or Risk Society?" Urban Studies, vol. 34, nos 5-6, halaman 845-871).

Hakim, Rustam., dkk. (2000). Persepsi Masyarakat terhadap Aspek Perencanaan Ruang Terbuka Hijau Kota Jakarta. http://rustam2000.worpress.com/per sepsi-masyarakat-terhadap-aspekperencanaan-ruang-terbuka-hijaukota-jakarta/, diunduh tanggal 30 Oktober 2010, jam 9.22.

Joga, Hirworo. dan Yori Antar (2010). Komedi Lenong: Satire Ruang Terbuka Hijau. Jakarta.

Kartodihardjo, Hariadi. dkk., (2008). Kajian Daya Dukung dan Kebijakan Pembangunan Pulau Jawa. Jakarta: Kementerian Koordinator Bidang Perekonomian.

Kebijakan Perumahan Pemerintah Jangan Sampai Ketinggalan Momentum, http://www.antaranews.com/berita/ 1268519741/kebijakan-perumahanpemerintah-jangan-sampai-

ketinggalan-momentum, diunduh tanggal 30 Oktober 2010, jam 8.27.

Menuju Kebijakan Perumahan yang Memihak Rakyat. http://yaminsh.wordpress. com/2008/10/11/menuju-kebijakanperumahan-yang-memihak-rakyat/, diunduh tanggal 30 Oktober 2010, jam 8.14

"Pembahasan RTRW: Permukiman jadi Vertikal”. Kompas, Selasa 19 Oktober 2010, hlm. 26 kolom 1-3.
Ribot, Jesse C., and Nancy Lee Peluso. (2003), "A Theory of Access", Rural Sociology, June 2003, page 153-181.

RTH disesuaikan dengan Kebutuhan, http://www.poskota.co.id/beritaterkini/2010/03/26/rth-disesuaikandengan-kebutuhan, diunduh tanggal 30 Oktober 2010 jam 9.14

Suparlan, Parsudi. (2004). Masyarakat dan Kebudayaan Perkotaan: Perspektif Antropologi Perkotaan. Jakarta: Yayasan Pengembangan Kajian Ilmu Kepolisian (YPKIK).

Sutton, Rebecca. (1999). The Policy Process: An Overview. London: Overseas Development Institute.

Undang-Undang Nomor 16 tahun 1985 tentang Rumah Susun. (1985)

Undang-Undang Rumah Susun harus Segera Direvisi Kembali, 27 September 2010. http://butuhtips.com/undangundang-rumah-susun-harus-segeradi-revisi-kembali.html, diunduh tanggal 21 Desember 2010 pukul 23.46

Understanding Policy Process: A Review of IDS Research on The Environment. (2006). Institute of Development Studies, University of Sussex.

Wittmer, Heidi. and Regina Birner. Between Conservationism, EcoPopulism, and Developmentalism: Discourses in Biodiversity Policy in Thailand and Indonesia. 
40 JURNAL ILMIAH MIMBAR DEMOKRASI 